\title{
FISHERY BIOLOGY OF THE SWORDFISH (Xiphias gladius, LINNAEUS 1758) CAUGHT BY SURFACE LONGLINERS BASED IN ITAJAÍ, SOUTHERN BRAZIL
}

\author{
Ana Lia Campos Quaggio ${ }^{1 *}$, Rosângela P. T. Lessa ${ }^{2}$, Jorge Eduardo Kotas ${ }^{3}$ and Celson F. Lin ${ }^{3}$ \\ Consultora da Organização dos Estados Ibero-Americanos - OEI \\ (SHS Quadra 6 - Conjunto A - Bloco C - Ed. Brasil 21- Sala 919, 70.316-109 Brasília, DF, Brasil) \\ Universidade Federal Rural de Pernambuco - UFRPE \\ (Rua Dom Manoel de Medeiros, s/n, Dois Irmãos, 52171-900 Recife, PE, Brasil)
}

Centro de Pesquisa e Gestão de Recursos Pesqueiros do Litoral Sudeste e Sul - CEPSUL/ICMBio (Av. Ministro Victor Konder, n 374, Fundos do CENTREVENTOS 88301-700, Itajaí, SC, Brasil)

\section{A B S T R ACT}

\begin{abstract}
The Xiphias gladius (Linnaeus, 1758) data used in the present study were obtained from commercial fishing cruises of the pelagic longline fleet based in Itajaí, operating in the Southwest Atlantic. For the Covariance models, fishing effort (number of hooks) and catches $(\mathrm{kg})$ were pooled and categorized into the following groups: (1) year (1997, 1998, 2001, 2002 and 2007); (2) lunar phase; and (3) seasons, fishing effort being the covariate. The highest mean swordfish catch (kg) occurred during the waxing crescent moon and during wintertime. The Mantel-Haenszel procedure was applied to compare the efficiency of the two hooks tested, and showed that the "J" hook type (J 9/0 $10^{\circ}$ offset), traditionally used by the fleet, catches 1.2 -fold more Xiphias gladius than the circle hook $\left(18 / 010^{\circ}\right.$ offset), used as an optional device to reduce sea turtle bycatch. The conversion of individual dressed weight $(\mathrm{kg})$ into total length $(\mathrm{cm})$ from 2000 to 2002, showed that sub-adults represented $66 \%$ of the total catch.
\end{abstract}

\section{R ESUMO}

No presente estudo foram analisados os dados obtidos para Xiphias gladius (Linnaeus, 1758) através de observadores, mapas de bordo e fichas de desembarque de carcaças, coletadas pela frota de espinhel-de-superfície sediada em Itajaí (SC). Modelos de análise de covariância (ANCOVA) foram aplicados aos dados de captura (peso em kg) do espadarte, tendo como efeitos: (1) anos de 1997, 1998, 2001, 2002 e 2007 (2) fases lunares e (3) épocas do ano. A covariável foi o esforço de pesca ( ${ }^{\circ}$ de anzóis). As maiores médias de captura ocorreram durante as fases de lua crescente e no inverno. O procedimento estatístico de Mantel-Haenszel foi utilizado para comparar as capturas do espadarte no anzol tipo "Jota" ( $\mathrm{J}$ 9/0 $10^{\circ}$ offset), comumente utilizado pela frota, com o anzol tipo "circular" (18/0 10 offset), este último oferecido como alternativa mitigadora à captura de tartarugas marinhas. O teste M-H mostrou que o anzol "Jota" apresentou 1,2 mais chances de capturar Xiphias gladius que no "circular". A conversão dos pesos individuais das carcaças $(\mathrm{kg})$ em comprimentos totais $(\mathrm{cm})$, referentes aos anos de 2000 a 2002, indicou que $66 \%$ das capturas foram de sub-adultos ao longo de todo o ano.

Descriptors: Mantel-Haenszel test, Covariance models, Length composition.

Descritores: Teste de Mantel-Haenszel, Análise de covariância, Composição de tamanho.

\section{INTRODUCTION}

The swordfish, Xiphias gladius, is distributed throughout the continental slope and adjacent oceanic areas off the southeastern and southern regions of Brazil and is the second most important target species for the surface longline fleet based in the city of Itajaí, state of Santa Catarina, after the blue-shark, Prionace glauca (Linnaeus, 1758) (UNIVALI, 2007). Besides swordfish catches by longliners, there are also records of incidental catches by drift-net fisheries in the same area between 1993 and 2002. However, these cases only represented $0.1 \%$ of the total catch (KOTAS et al., 2005). There are also records from sport fisheries off southeastern Brazil (AMORIM AND ARFELLI, 2001).

The International Commission for the Conservation of Atlantic Tunas (ICCAT) is concerned about the considerable increase in swordfish catches in the South Atlantic, which could constitute overfishing. Following the enforcement of recommendations from this commission, which included the reallocation of 
the South Atlantic fleet to other oceans, the total catch of $X$. gladius in this area has been decreasing since 1995 (ICCAT, 2005). An annual quota of 15,000 thas been established for the stock in the South Atlantic from 2010 to 2012 (ICCAT, 2009).

Brazilian surface longliners based in the Santos and Itajaí harbors began targeting swordfish in 1994 and 1996, respectively. The fishing strategy is to deploy the longline in the evening, using artificial light attractors ("light sticks"). Such a fishing strategy is based on the nocturnal feeding behavior of the swordfish in shallow waters (CAREY and ROBINSON, 1981).

The aim of the present study is to contribute to the conservation of $X$. gladius in the Southwestern Atlantic through knowledge of the seasonal and lunar effects on catches and relative abundance levels as well the impact of the longline fleet based in Itajai (southern Brazil) on the size composition of the species. Additionally, the results of hook selectivity experiments for the swordfish in this area are shown.

\section{Material ANd Methods}

Preparing Data for Statistical Analysis

The swordfish catch and fishing effort data used in the present study were taken from the log books of surface longliners stationed in Itajaí for 1997, 1998, 2001, 2002 and 2007, provided by the Fishery Statistics Section of the Fishery Research and Management Center of Southeastern and Southern Brazil (CEPSUL). A total of 1943 deployments were analyzed.

For the spatial-temporal modeling, fishing effort (number of hooks) and catches $(\mathrm{kg})$ were pooled and categorized into the following groups: (1) year (1997, 1998, 2001, 2002 and 2007); (2) season (spring, summer, autumn and winter), and (3) lunar phase (waxing crescent, waning crescent, full moon and new moon). Catch per unit effort (CPUE, kg/1000 hooks) values were plotted quarterly on maps to study the dynamics of the Itajaí longline fleet (Fig. 1).

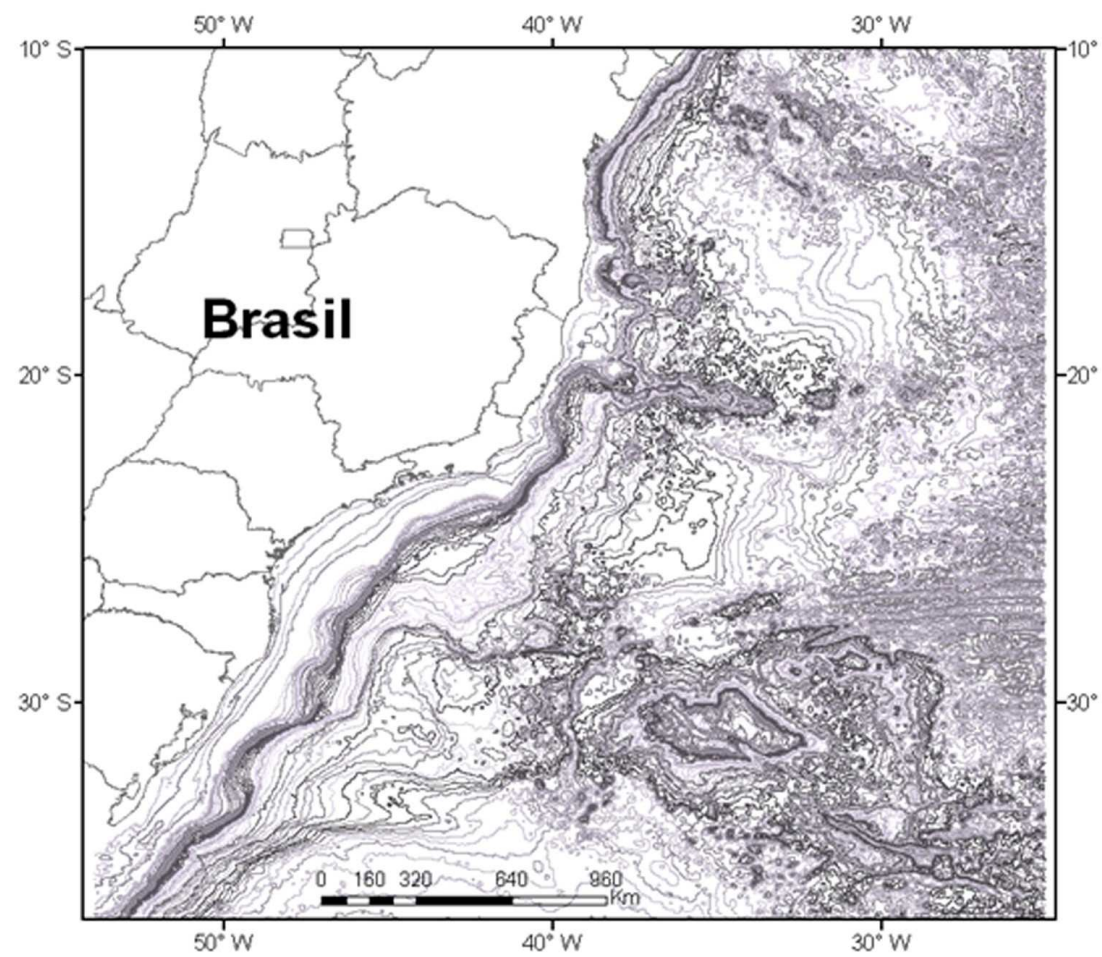

Fig. 1. Fishing area of the longline fleet based in Itajaí, southern Brazil.

Analysis of Covariance

Multiple analysis of covariance (ANCOVA), with three factors, i.e., year, season and lunar phase
(PETRERE, 1978; HUITEMA, 1980; ABUABARA, 1996), was applied to the swordfish catch versus longline fishing effort data in order to study the effects 
of these factors on catches. Fishing effort was the covariate. For such, the following model was used:

$$
Y_{i j k}=\mu+\alpha_{i}+\pi_{j}+\gamma_{k}+\beta\left(X_{1 j j k}-\bar{X}_{1 \ldots}\right)+\varepsilon_{i j k}
$$

Eq. 1.

in which swordfish catch $(\mathrm{kg})$ in year $i$, season $j$ and lunar phase $k$; population mean; year effect $(i=1, \ldots$, $5)$; = season effect $(j=1,2,3,4) ;=$ lunar phase effect $(k=1,2,3,4) ;$ angular coefficient of the effort covariate; covariate value (number of hooks) for year $i$, season $j$ and lunar phase $k$; overall mean for all individual fishing efforts; = random error component, considering normal distribution $\mathrm{N}\left(0 ; \sigma^{2}\right)$.

From this formula, the magnitude of the adjusted means to be compared by the different models is a function of (1) the difference between the mean covariate within each group and the overall mean covariate for all observations and (2) the angular regression coefficient:

$$
\beta\left(X_{i j k l}-\bar{X}_{\ldots}\right)
$$

To obtain a more balanced experimental design and reduce the lack of control over fishing effort, individual observations were added to groups related to years, seasons and lunar phases. This procedure helped reduce the variability in the catch and effort data (ALLEN, 1980; PETRERE, 1978). The analysis of covariance was performed with these grouped data.

After fitting the data to the linear regression and ANCOVA models, the Lilliefors normality test (1967) was applied to determine whether there was non-linearity and heterogeneity in the residual variances. The presence of autocorrelation was determined using the Durbin-Watson test (1951). Comparisons between two adjusted means were performed using Tukey's test (1953).

\section{The Mantel-Haenszel procedure}

When studying the relationship between swordfish catches and different types of hooks, another variable may be associated with the catches, types of hooks or both, such that the true relationship between catches and different types of hooks is masked. This is known as a "masking variable", which, in the present case, could be size composition, fishing area, season, temperature, etc... The MantelHaenszel (MH) procedure (Mantel and Haenszel, 1959; Daniel, 1995) is the statistical method used to control this third variable. This procedure is used in experimental designs to test the efficiency of a particular treatment (e.g. does a circle hook increase the swordfish catch?). However, as this is an experiment, it is important to have a control (e.g. the $\mathbf{J}$ hook commonly used by the longline fleet).

The MH procedure was applied to swordfish catch data (number of individuals) from hook selectivity experiments performed by observers aboard commercial longline vessels based in Itajaí operating in the Southwestern Atlantic from 2004 to 2008. The traditional J hook used by the commercial fleet $(9 / 0$ $10^{\circ}$ offset) was compared with the circle hook $(18 / 0$ $10^{\circ}$ offset) provided by the TAMAR project (Fig. 2).

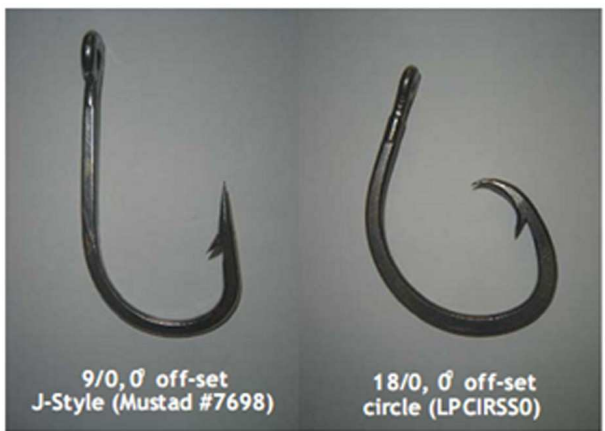

Fig. 2. Hook types compared in the selectivity tests involving the surface longline fleet based in Itajaí (southern Brazil) operating in the Southwestern Atlantic from 2004 to 2008.

The $\mathrm{J}$ hook was the control while the circle hook was tested. By definition, the test group was the initial longline section composed of 500 hooks - 250 circle and $250 \mathrm{~J}$ hooks, which were alternately arranged along the mainline (i.e., J, Circle, J, Circle, J, Circle, J ...) (Fig. 3). The baits used were mackerel (Scomber japonicus) and squid (Illex argentinus). A total of 190 deployments were analyzed among a total of 24 cruises between 2004 and 2008 . 


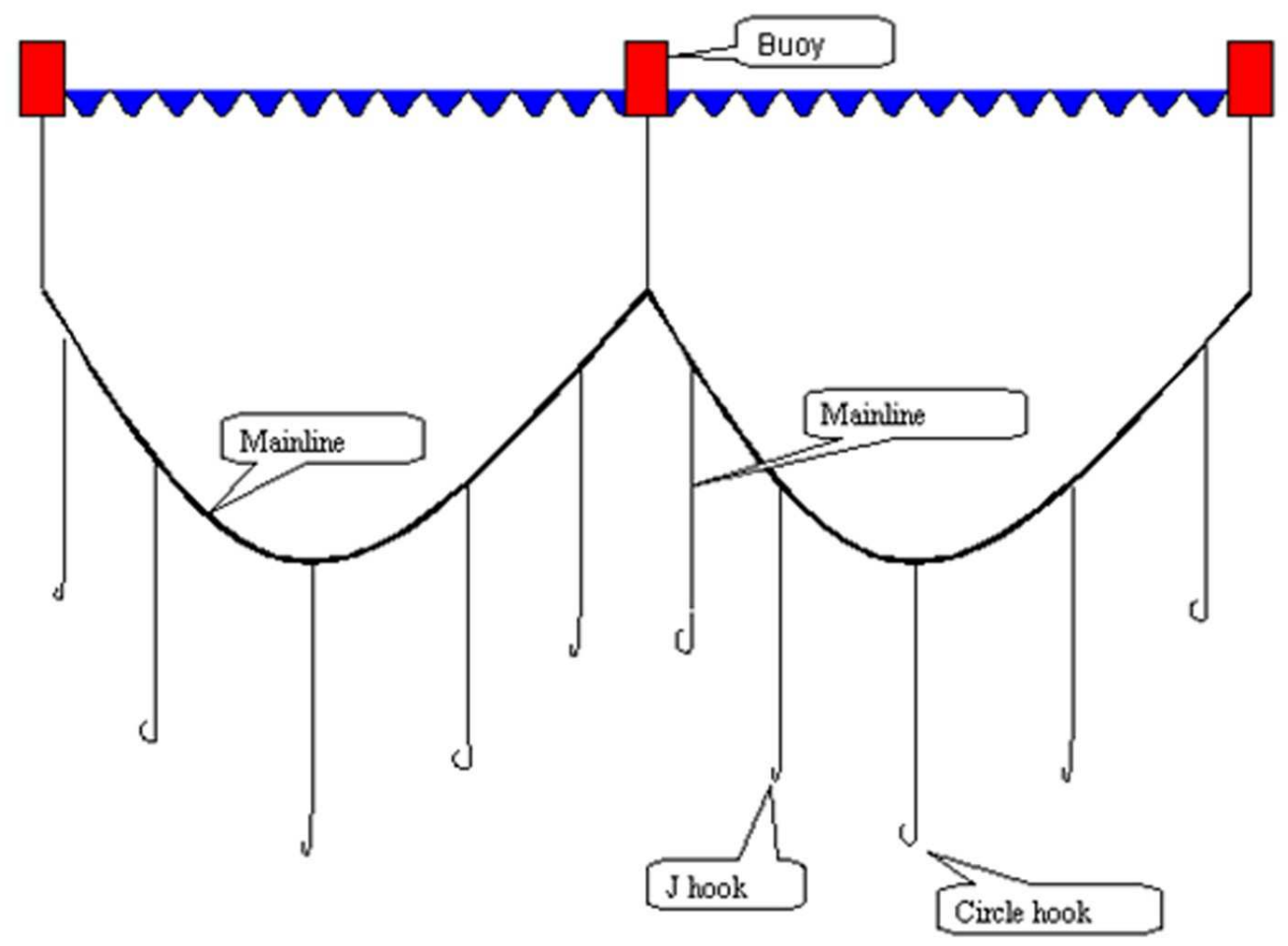

Fig. 3. Test group design developed by TAMAR project for experiments on commercial longline hook selectivity. Assessment of Impact of Itajaí Longline Fleet on
Swordfish Size Structure

This analysis was based on the dressed weights of swordfish carcasses landed in Itajaí (Santa Catarina, Brazil) by the industrial longline fleet from 2000 to 2002, obtained from "Comércio e Indústria de Pescados Kowalsky Ltda." A total of 7460 carcasses were weighed. The conversion of individual dressed weight $(\mathrm{kg})$ into total length $(\mathrm{cm})$ was performed using the length-weight relationship proposed by ARFELLI (1996):

$\mathrm{LJFL}=1.91 * \mathrm{DW}^{0.925}$

in which, DW = dressed weight in $\mathrm{kg}$ and LJFL = lower jaw to fork length measure used by ICCAT.

To assess swordfish size composition caught by the longliners, three LJFL classes were established, following the procedures described by Hazin et al. (2001), categorizing the reproductive stages of swordfish into three classes:
(1) JUVENILES (LJFL < $125 \mathrm{~cm}$ );

(2) MATURING/MATURE $(125 \leq \mathrm{LJFL} \leq 170 \mathrm{~cm})$;

(3) ADULTS $>170 \mathrm{~cm}$.

\section{Results}

Swordfish Size Composition in Itajaí Longliner Catches

For the period between 2000 and 2002, mean swordfish size of the specimens caught by longliners based in Itajaí was $155.6 \mathrm{~cm}$ LJFL [ $\mathrm{n}=7459$; standard deviation $(\mathrm{SD})=25.3]$. The proportion of maturing/mature individuals was high, accounting for $66 \%$ of the catches. However, $8.2 \%$ were juveniles and below the minimum catch size established by ICCAT. Adults represented only $26 \%$ of the total catch (Fig. 4). The lowest $(69.9 \mathrm{~cm})$ and highest (274.4 cm LJFL) values occurred in 2000 and 2002, respectively.

Seasonally, the mean swordfish size (LJFL) fluctuated little, with values ranging from a minimum of $150.1 \mathrm{~cm}$ in autumn to a maximum of $161 \mathrm{~cm}$ in summer. Autumn was the season with the largest proportion of juveniles in the catches (Table 1). 


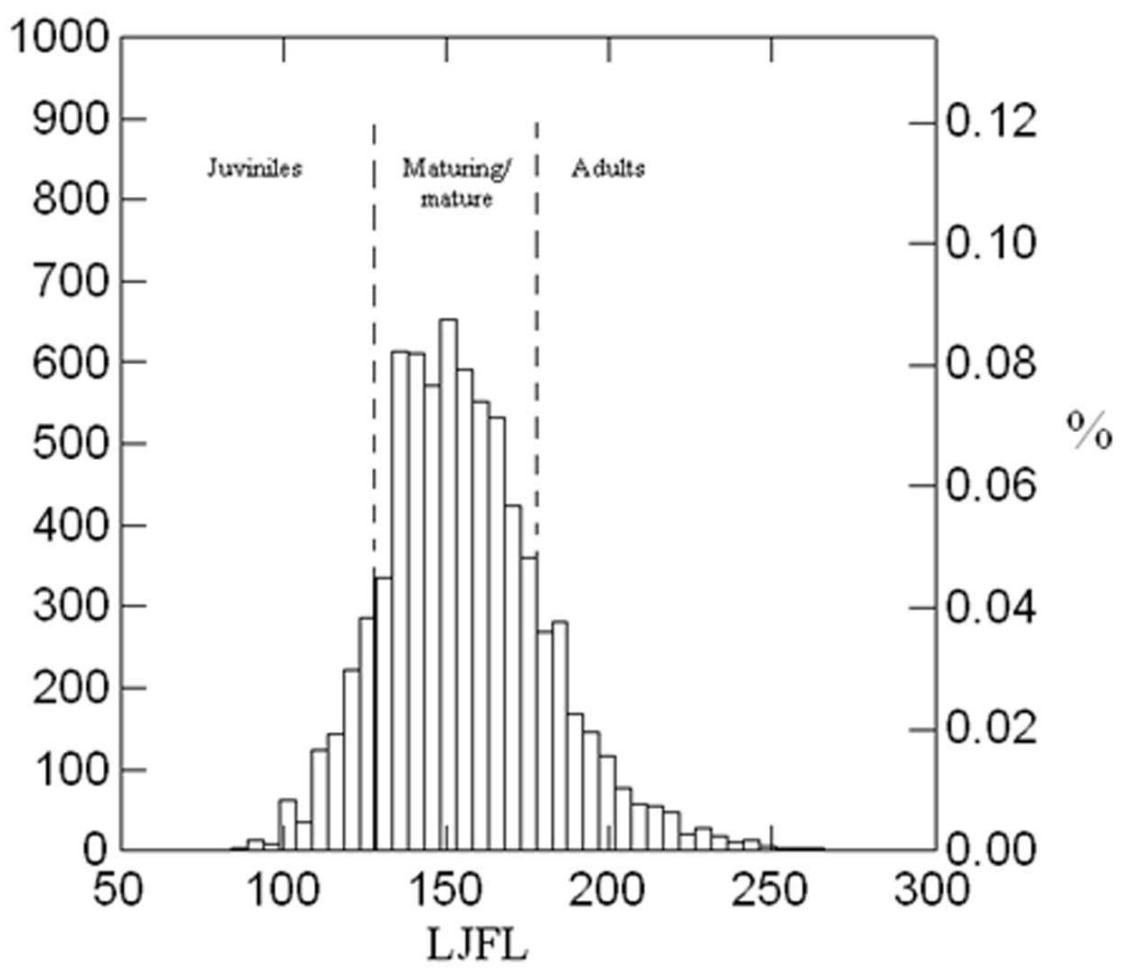

Fig. 4. Size composition of swordfish caught by longline fleet based in Itajaí (southern Brazil) between 2000 and 2002; LJFL - lower jaw to fork length $(\mathrm{cm})$; mean $=155.6 \mathrm{~cm}$; $\mathrm{n}=7459$; SD = $25.3 \mathrm{~cm}$.

Table 1. Seasonal distribution of mean size (LJFL) of swordfish caught by Itajaí longliners off southeastern and southern Brazil from 2000 to 2002.

\begin{tabular}{ccccc}
\hline \hline & Spring & Summer & Autumn & Winter \\
\hline Mean size (cm) & 154.7 & 161.0 & 150.1 & 159.6 \\
SD (cm) & 24 & 25.6 & 23.4 & 26.6 \\
$\mathrm{n}$ & 1687 & 967 & 2402 & 2403 \\
\hline
\end{tabular}

The highest proportion of adults and maturing/mature individuals occurred in 2001. In 2002 , there was a higher proportion of juveniles than in the previous years. Mean size decreased throughout the period from $161.7 \mathrm{~cm}$ in 2000 to $149.6 \mathrm{~cm} \mathrm{LJFL} \mathrm{in}$ 2002 (Table 2).

Table 2. Annual distribution of mean size (LJFL) of swordfish caught by Itajaí longliners off southeastern and southern Brazil from 2000 to 2002.

\begin{tabular}{crrr}
\hline \hline & $\mathbf{2 0 0 0}$ & $\mathbf{2 0 0 1}$ & $\mathbf{2 0 0 2}$ \\
\hline Mean size (cm) & 161.7 & 156.9 & 149.6 \\
SD (cm) & 23.9 & 25.0 & 25.2 \\
$\mathrm{n}$ & 1170 & 4204 & 2085 \\
\hline
\end{tabular}

There were monthly differences in mean swordfish size (LJFL) between 2000 and 2002, with a minimum of $128 \mathrm{~cm}$ in September to a maximum of $194.9 \mathrm{~cm}$ in July, both in the austral winter (Fig. 5).

Analysis of Variance (ANOVA) and Covariance (ANCOVA) Models Applied to Swordfish Catch and Fishing Effort Data from Longliners Based in Itajaí

The data on swordfish catch $(\mathrm{kg})$ versus fishing effort (numbers of hooks) were plotted on a graph, revealing a positive linear relationship between these variables, which is an essential condition for covariance analysis models (HUITEMA, 1980) (Fig. 6). 


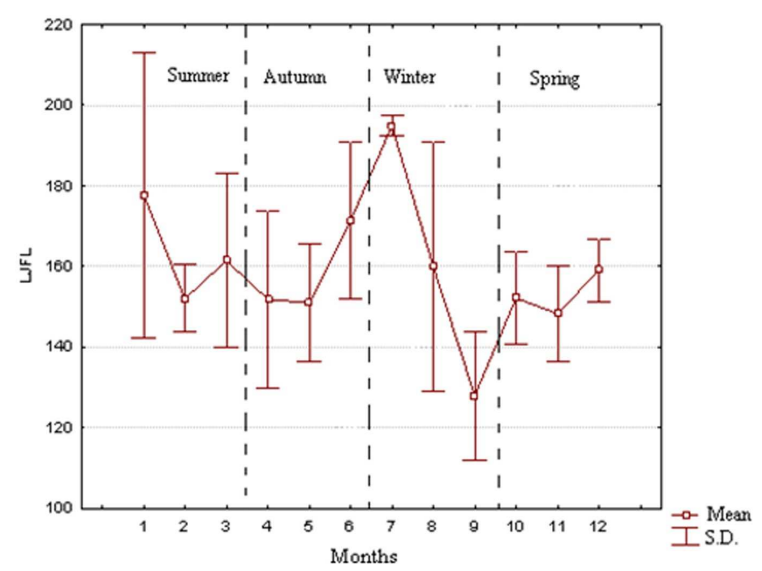

Fig. 5. Monthly behavior of mean size (LJFL) of swordfish caught by Itajaí longliners off southeastern and southern Brazil from 2000 to 2002; LJFL - lower jaw to fork length $(\mathrm{cm})$.

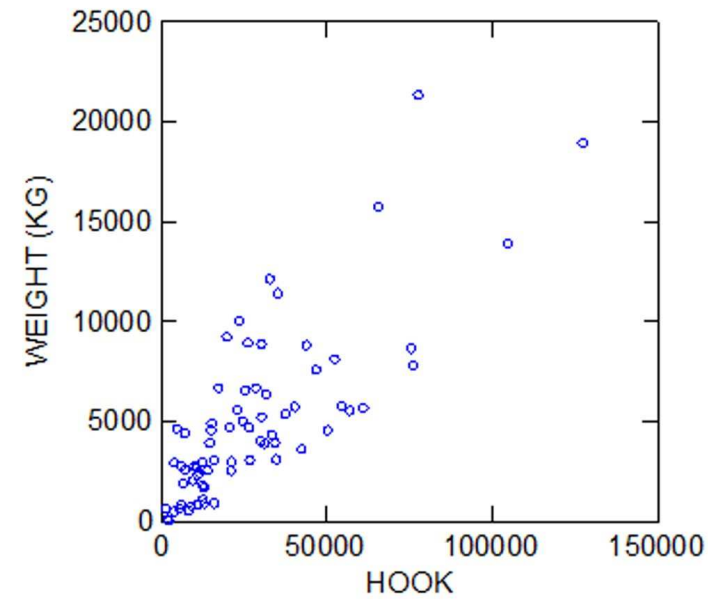

Fig. 6. Scatterplot of swordfish catches and fishing effort from longline fleet based in Itajaí; period: 1997, 1998, 2001, 2002 and 2007; WEIGHT (KG) - accumulated catch (kg); HOOK - accumulated fishing effort (number of hooks)

The linear regression model revealed good correlation between the variables $\left(\mathrm{r}^{2}=0.62\right)$. The intersection $(\mathrm{a}=1225.8 \mathrm{~kg})$ and slope $(\mathrm{b}=0.14)$ were significant $(\mathrm{P}<0.01)$, with standard errors of S.E. $\cdot \mathrm{a}=$ $477.6 \mathrm{~kg}$ and S.E.b $=0.013$, respectively. The analysis of variance indicated that the variation explained by the regression line $\left(\mathrm{MS}=7.61 * 10^{8}\right)$ was greater than the residual $(\mathrm{MS}=6908147.9)$, with the slope different from zero $(\mathrm{P}<0.01)$. The Durbin-Watson test $(\mathrm{D}=1.56)$ revealed low autocorrelation (22\%). Therefore, the linear regression model was a good fit, which is a condition for the use of fishing effort as a covariate in the ANCOVA models. The distribution of residuals was relatively uniform, with some extreme values, but mostly between -5000 and $+5000 \mathrm{~kg}$. The Lilliefors test was applied to the residuals of the regression model and the results $\left[D_{\text {obs }}(0.125)<D_{\text {critical }}\right.$ (0.131)] confirmed normal distribution. The linear regression model between catch and fishing effort was defined by the following equation:

Weight $(\mathrm{kg})=1225.8+0.14 *($ number of hooks $)(\mathrm{n}=$ $\left.70 ; \mathrm{r}^{2}=0.62\right)$

Eq. 4

Therefore, the following Multiple Analysis of Covariance model with three factors was fitted to the data: 
Weight $(k g)=$ Constant + Season + Moon + Year + Hook

Eq. 5

in which weight $=$ dependent variable; constant $=$ population mean common to all observations; season = seasonal effect; moon = lunar effect; year $=$ year effect; hook = fishing effort covariate (number of hooks).

The model demonstrated strong correlation $\left(\mathrm{r}^{2}=0.83\right)$. The effects of year, season, lunar phase and the covariate fishing effort were significant $(\mathrm{P}<$ 0.01). Fishing effort accounted for most of the variation $\left(\mathrm{MS}=6.84 * 10^{8}\right)$, followed by season, year and lunar phase, in descending order of importance. The Durbin-Watson test $(\mathrm{D}=2.26)$ indicated low residual autocorrelation (16\%) (Table 3). The Lilliefors test was applied to the residuals of the model and the results $\left(\mathrm{D}_{\text {obs }}(0.085)<\mathrm{D}_{\text {critical }}(0.131)\right)$ confirmed normal distribution. Therefore, the model had a good fit to the data.

The highest mean swordfish catch $(\mathrm{kg})$ occurred during the waxing crescent moon (Fig. 7). However, comparing the means using Tukey's test, there were only significant differences between the waxing and waning crescent moons (Table 4).

Swordfish catches were considerably higher in winter than other seasons (Fig. 8). Tukey's test demonstrated that this difference between winter and the other seasons was significant (Table 5).

Table 3. Results of the analysis of covariance model fitted to swordfish catch $(\mathrm{kg})$ and fishing effort (number of hooks) data from longliners based in Itajaí; years: 1997, 1998, 2001, 2002 and 2007; model: Weight $(\mathrm{kg})=$ Constant + Season + Moon + Year + Hook $; \mathrm{n}=70 ; \mathrm{r} 2=0.83 ; \mathrm{F}=$ Fisher test $; \mathrm{P}=$ significance.

\begin{tabular}{lccccc}
\hline \hline Source & Sum of Squares & $\begin{array}{c}\text { Degrees of } \\
\text { Freedom }\end{array}$ & Mean Square & F & P \\
\hline Season & $1.11 \mathrm{E}+08$ & 3 & $3.71 \mathrm{E}+07$ & 10.24 & 0.000 \\
Moon & $5.02 \mathrm{E}+07$ & 3 & $1.67 \mathrm{E}+07$ & 4.61 & 0.006 \\
Year & $8.44 \mathrm{E}+07$ & 4 & $2.11 \mathrm{E}+07$ & 5.82 & 0.001 \\
Hook & $6.83 \mathrm{E}+08$ & 1 & $6.84 \mathrm{E}+08$ & 188.51 & 0.000 \\
Error & $2.10 \mathrm{E}+08$ & 58 & 3625940.04 & & \\
\hline
\end{tabular}

Table 4.Tukey's test applied to fitted mean swordfish catches $(\mathrm{kg})$ with the covariance model for different lunar phases; years: 1997, 1998, 2001, 2002 and 2007; model: Weight $(k g)=$ Constant + Season + Moon + Year + Hook; Ho: equal means.

\begin{tabular}{lccccc}
\hline \hline Lunar phases & Difference & $\begin{array}{c}\text { Standard } \\
\text { Error }\end{array}$ & $\boldsymbol{q}$ & $\boldsymbol{q}(\mathbf{0 . 0 5} ; \mathbf{5 8 ; ~ 4 )}$ & Conclusion \\
\hline waxing crescent X full moon & 1468.28 & 455.37 & 3.22 & 3.73 & Accept Ho \\
waxing crescent X new moon & 1575.67 & 461.83 & 3.41 & 3.73 & Accept Ho \\
waxing crescent X waning crescent & 2369.15 & 455.37 & 5.20 & 3.73 & Reject Ho \\
full moon X new moon & 107.39 & 455.37 & 0.24 & 3.73 & Accept Ho \\
full moon X waning crescent & 900.87 & 448.82 & 2.01 & 3.73 & Accept Ho \\
new moon X waning crescent & 793.48 & 455.37 & 1.74 & 3.73 & Accept Ho \\
\hline
\end{tabular}

Table 5. Tukey's test applied to fitted mean swordfish catches $(\mathrm{kg})$ with the covariance model for different seasons; years: 1997, 1998, 2001, 2002 and 2007; model: Weight $(k g)=$ Constant + Season + Moon + Year + Hook; Ho: equal means.

\begin{tabular}{|c|c|c|c|c|c|}
\hline Seasons & Difference & $\begin{array}{c}\text { Standard } \\
\text { Error }\end{array}$ & $q$ & $q(0.05 ; 58 ; 4)$ & Conclusion \\
\hline winter $\mathrm{X}$ summer & 2104 & 451.62 & 4.66 & 3.73 & Reject Ho \\
\hline winter $\mathrm{X}$ autumn & 2971 & 431.36 & 6.89 & 3.73 & Reject Ho \\
\hline winter X spring & 3042 & 459.91 & 6.61 & 3.73 & Reject Ho \\
\hline summer $\mathrm{X}$ autumn & 867 & 456.87 & 1.90 & 3.73 & Accept Ho \\
\hline summer X spring & 938 & 483.92 & 1.94 & 3.73 & Accept Ho \\
\hline autumn X spring & 71 & 465.06 & 0.15 & 3.73 & Accept Ho \\
\hline
\end{tabular}




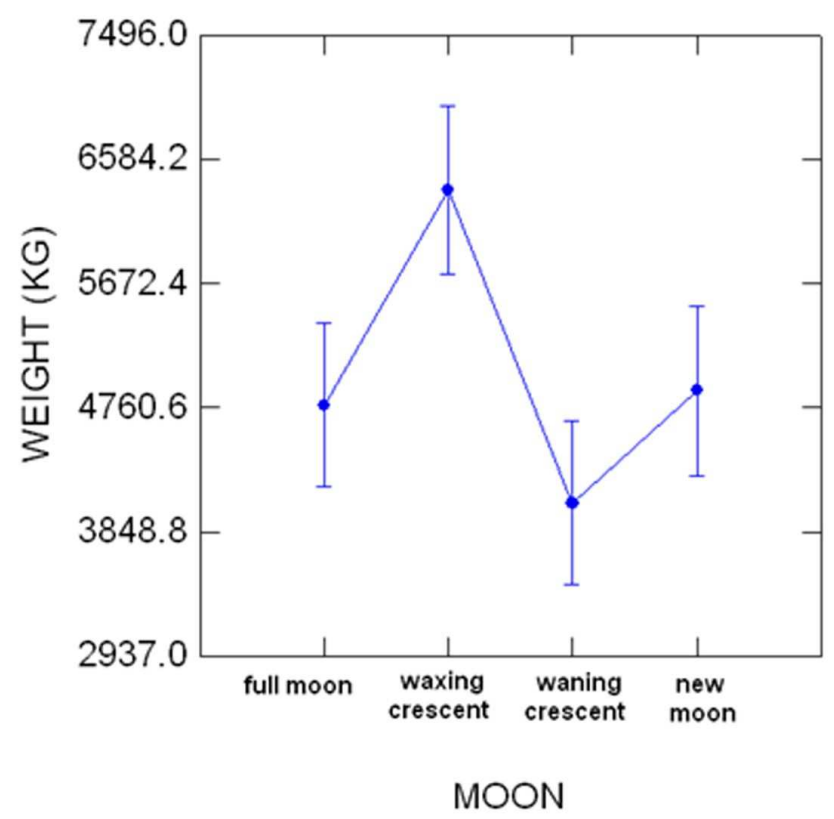

Fig. 7. Trend in swordfish catch $(\mathrm{kg})$ means by lunar phase fitted to the ANCOVA model; accumulated catch data for 1997, 1998, 2001, 2002 and 2007.

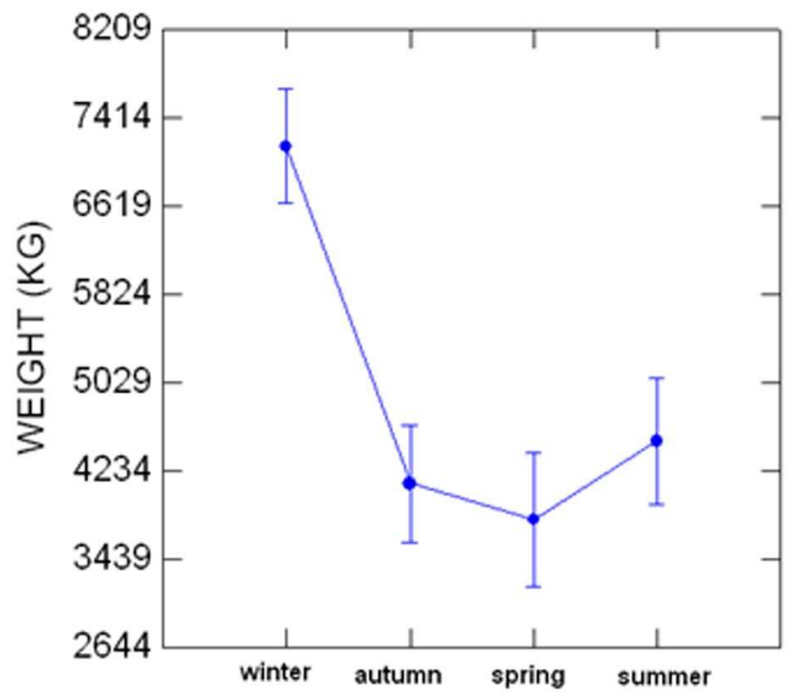

SEASON

Fig. 8. Trend in swordfish catch $(\mathrm{kg})$ means by season fitted to ANCOVA model; accumulated catch data for 1997, 1998, 2001, 2002 and 2007. 
Between 1997 and 2002, there was a considerable decrease in swordfish catches, likely due to the greater concentration of fishing effort targeting other pelagic species, such as the blue shark, Prionace glauca (Fig. 9). From 2000 to 2002, there was an increase in the proportion of blue shark and a decrease in swordfish catches among the pelagic longline fisheries (Fig. 10) (UNIVALI, 2001，2002，2003, 2004, 2005, 2006, 2007, 2008, 2009). In 2007, swordfish catches recovered, but not to the same degree as that of 1997 . Tukey's test revealed significant differences between 1997 and both 2001 and 2002 as well as between 2002 and both 1998 and 2007 (Table 6).

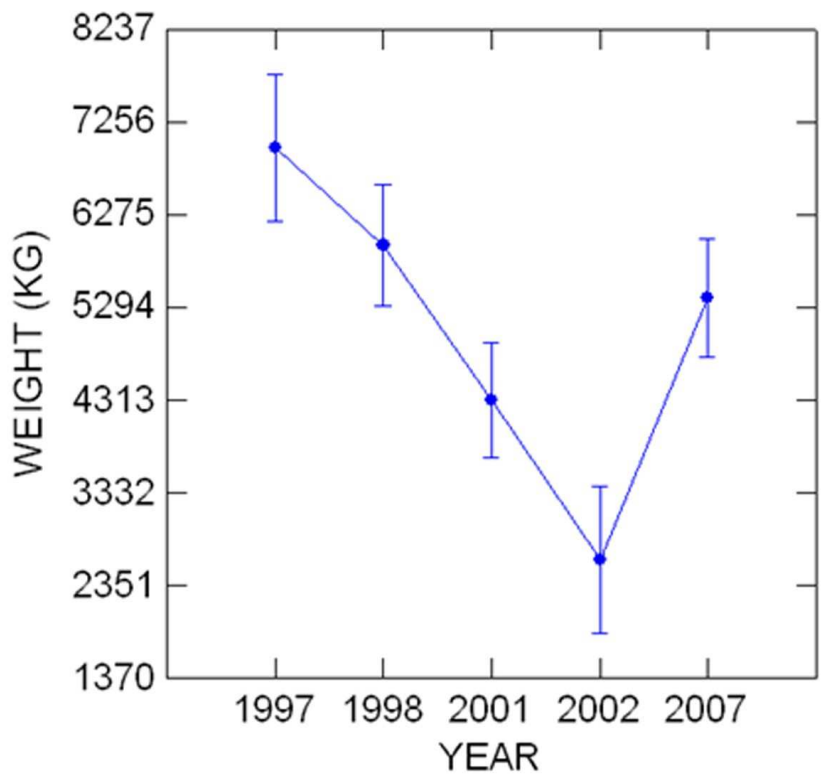

Fig. 9. Trend in swordfish catch $(\mathrm{kg})$ means by year fitted to the ANCOVA model; accumulated catch data for 1997, 1998, 2001, 2002 and 2007.

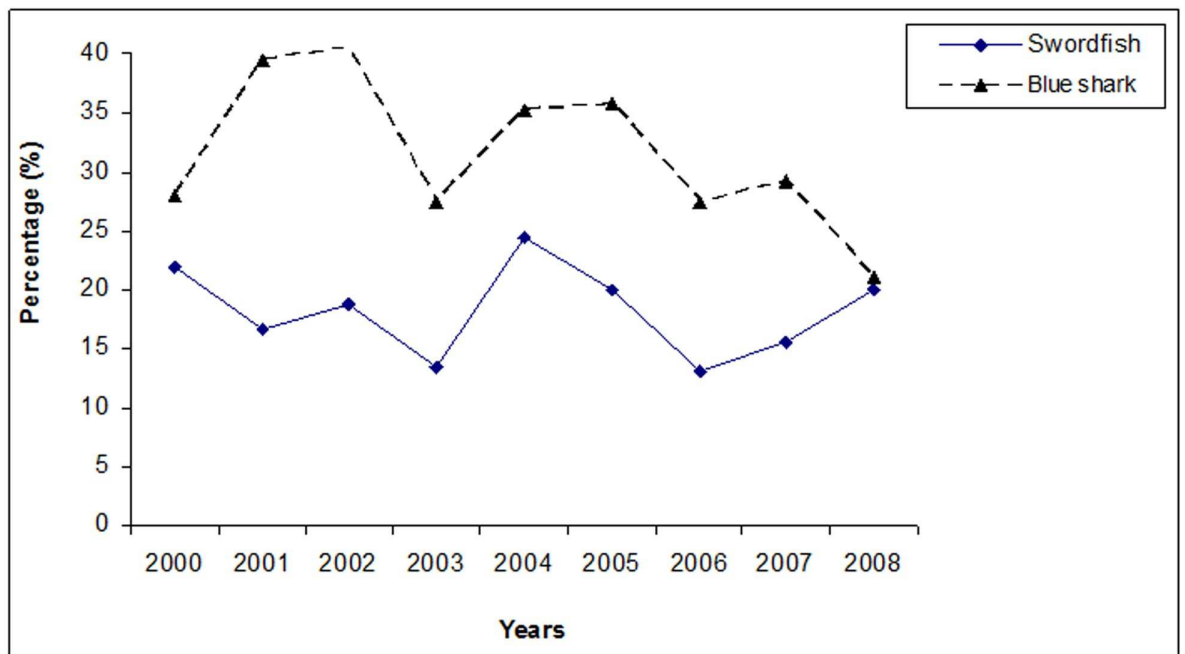

Fig. 10. Trends in annual proportions (\%) of swordfish and blue shark catches from the longliners based in Itajaí; period: 2000 to 2008; source: UNIVALI (2001, 2002, 2003, 2004, 2005, 2006, 2007, 2008, 2009). 
Table 6. Tukey's test applied to fitted mean swordfish catches $(\mathrm{kg})$ with the covariance model for different years; years: 1997, 1998, 2001, 2002 and 2007; model: Weight $(k g)=$ Constant + Season + Moon + Year + Hook; Ho: equal means.

\begin{tabular}{lccccc}
\hline \hline Years & Difference & $\begin{array}{c}\text { Standard } \\
\text { Error }\end{array}$ & $\boldsymbol{q}$ & $\boldsymbol{q}(\mathbf{0 . 0 5} ; \mathbf{5 8 ;}$ 4) & Conclusion \\
\hline 1997 X 1998 & 827.73 & 534.49 & 1.55 & 3.97 & Accept Ho \\
1997 X 2007 & 1452.62 & 534.49 & 2.72 & 3.97 & Accept Ho \\
1997 X 2001 & 2403.33 & 527.38 & 4.56 & 3.97 & Reject Ho \\
1997 X 2002 & 4195.17 & 551.61 & 7.61 & 3.97 & Reject Ho \\
1998 X 2007 & 624.88 & 491.66 & 1.27 & 3.97 & Accept Ho \\
1998 X 2001 & 1575.60 & 483.92 & 3.26 & 3.97 & Accept Ho \\
1998 X 2002 & 3367.43 & 510.22 & 6.60 & 3.97 & Reject Ho \\
2007 X 2001 & 950.71 & 483.92 & 1.96 & 3.97 & Accept Ho \\
2007 X 2002 & 2742.55 & 510.22 & 5.38 & 3.97 & Reject Ho \\
2001 X 2002 & 1791.84 & 502.76 & 3.56 & 3.97 & Accept Ho \\
\hline
\end{tabular}

Hook Selectivity Experiments

The Mantel-Haenszel $(\mathrm{MH})$ procedure was applied to the swordfish catch data obtained from the longline hook selectivity experiments off the southeastern and southern regions of Brazil: $\mathrm{MH} \chi_{\mathrm{obs}}^{2}$ (10.1) > MH $\chi_{\text {critical }}^{2}$ (3.8). Therefore, a significant difference $(\mathrm{P}<0.01)$ was found between the two hooks tested, with the J hook catching 1.2-fold more swordfish than the circle hook (Table 7).

Table 7. Results of the MH procedure applied to swordfish catches (number of individuals) using two hook types ( $\mathrm{J}$ and circle) aboard longliners based in Itajaí; period: 2004 to 2008 .

\begin{tabular}{cccc}
\hline \hline & Positive & Negative & Total \\
\hline $\mathrm{C}$ & 715 & 106219 & 106934 \\
$\mathrm{~J}$ & 833 & 105055 & 105888 \\
Total & 1548 & 211274 & 212822 \\
\hline
\end{tabular}

Mantel-Haenszel statistic $=0.85$
Mantel-Haenszel Chi-square $=10.104$
Probability $=0.001$

The odds ratio (cross-product ratio) for the J hook was $(833 / 105055) /(715 / 106219)=1.2$

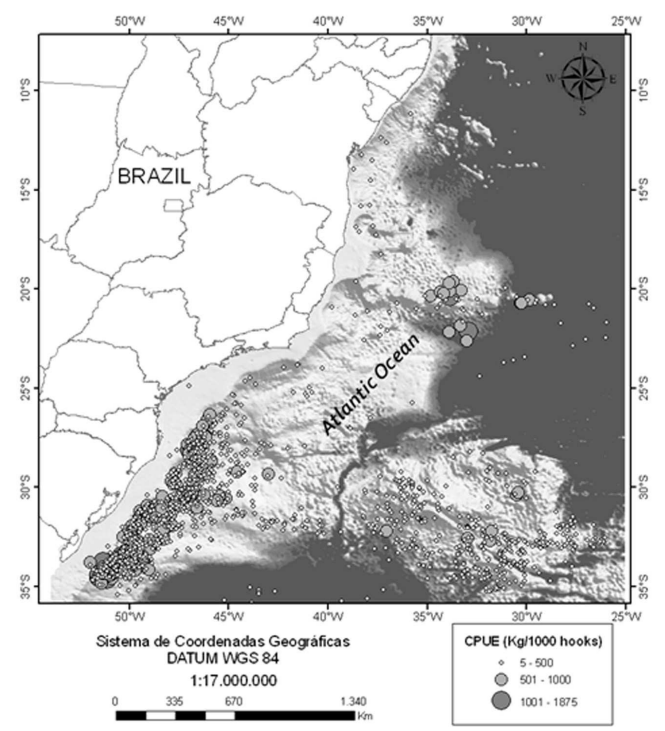

Distribution of Relative Abundance (CPUE)

In 1997，1998，2001，2002 and 2007, the greatest relative abundance (CPUE, $\mathrm{kg} / 1000$ hooks) occurred on the continental slope off southern Brazil at depths between 200 and $3000 \mathrm{~m}$ (Fig. 11). In descending order of importance, fishing efforts were mainly concentrated on the southern Brazilian slope, Rio Grande plateau and around the Trindade-Vitória seamounts.

Seasonally, the highest CPUE values occurred during the autumn-winter period (maximum of $1875 \mathrm{~kg} / 1000$ hooks) on the continental slope off the states of Santa Catarina and Rio Grande do Sul and around the Trindade-Vitória seamounts. Conversely, CPUE values were lower in the spring than the previous seasons, but remained concentrated on the continental slope off Santa Catarina and Rio Grande do Sul. It is important to consider that the sampling effort was lower in spring than the other seasons. In summer, the fleet expanded its fishing effort to the Rio Grande Plateau, but the highest CPUE values were around the Trindade-Vitória seamounts (Fig. 12).

Fig. 11. Spatial CPUE (kg/1000 hooks) distribution observed for swordfish caught by longliners based in Itajaí; years: 1997, 1998, 2001, 2002 and 2007. 

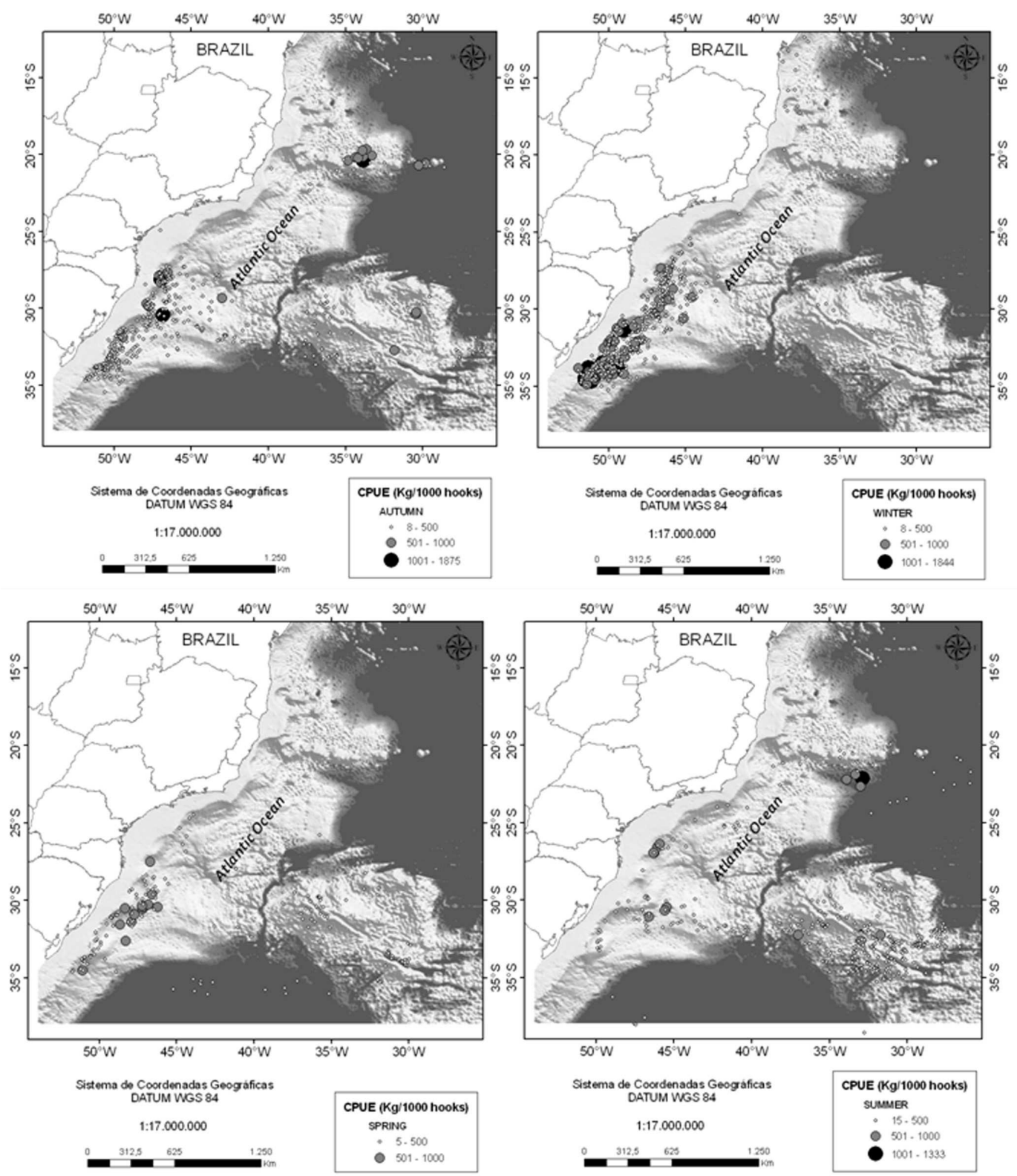

Fig. 12. Spatial distribution of seasonal CPUE (kg/1000 hooks) observed for swordfish caught by longliners based in Itajaí; years: 1997, 1998, 2001, 2002 and 2007.

\section{DisCUSSION}

From 2000 to 2009, industrial surface longliners based mainly in Itajaí landed a total of 2377 $\mathrm{t}$ of tunas $(13.2 \%$ of total catch), $7821 \mathrm{t}$ of sharks $(43.3 \%)$ and $2919 \mathrm{t}$ of swordfish $(16.2 \%)$ in the state of Santa Catarina (southern Brazil) (UNIVALI, 2001, 2002, 2003, 2004, 2005, 2006, 2007, 2008, 2009). Therefore, the swordfish was the second most important commercial species caught, surpassed only by sharks, a group represented mainly by the blue shark, Prionace glauca. For this period, the annual 
trends revealed a considerable increase in shark catches until 2002, when a peak of more than 1200 t was reached, followed by a decline, with a total of only $400 \mathrm{t}$ in 2009. Conversely, swordfish catches, although lower than sharks, remained stable (between 200 and $400 \mathrm{t}$ ) throughout the years.

The trends in relative abundance levels (CPUE, $\mathrm{kg} /$ trip) for the target species (sharks, tunas and swordfish) caught by the Itajaí longliners between 2000 and 2008 demonstrate a general decline until 2003 , followed by stabilization at lower levels until 2008. However, it is interesting to observe that the steepest decline, which occurred between 2000 and 2003, was caused by a sudden increase in longline fishing effort, i.e., from eight boats in 2000 to 72 in 2003. From 2004 onwards, the CPUE stabilized at higher levels of fishing effort.

Among the longline landings analyzed in the present study, there was a high percentage of maturing/mature swordfish, i.e., between $125-170 \mathrm{~cm}$ (LJFL), mainly in May, August and October. Hazin and Erzini (2008) report the same condition along the inter-tropical convergence zone. However, the authors found that swordfish adults were distributed mainly off the southern and southeastern regions of Brazil. Therefore, the high percentage of maturing/mature and juvenile swordfish $(74 \%)$ in the catches of longliners operating off southeastern and southern Brazil is a sign of overfishing. This situation contributes to the decline in the relative abundance of swordfish, thereby threatening the sustainability of the South Atlantic stock, which is a major concern for ICCAT. Therefore, the policy of monitoring the minimum swordfish landing size of $125 \mathrm{~cm}$ (LJFL) is an important management action necessary for the conservation of Xiphias gladius in the Southwestern Atlantic. However, considering that the $\mathrm{L}_{50}$ for female swordfish is $154 \mathrm{~cm} \mathrm{LJFL,} \mathrm{this} \mathrm{minimum} \mathrm{size} \mathrm{should}$ be reassessed. The present study also confirms the hypothesis that the adjacent oceanic areas off southeastern and southern Brazil are spawning areas for swordfish, as juveniles and maturing/mature individuals occur there throughout the year, mainly in autumn and winter.

A significant relationship $(\mathrm{P}<0.01)$ was found between lunar phase and swordfish catch $(\mathrm{kg})$, with the highest values attained during the waxing crescent moon. Hazin et al. (2002) analyzed data from longline fisheries off northeastern Brazil and found a similar relationship, with the highest catch rates during the new moon and waxing crescent moon. This phenomenon may be explained by the stronger attraction power of lightsticks under conditions of lower moonlight levels. However, without using lightsticks, Draganik and Cholyst (1988) found higher catch rates during the full moon. In this case, when the thermocline is located in deeper waters, full moonlight penetrates deeper in the water column than new moonlight, thereby stimulating feeding activity among swordfish, which can see their prey better.

The swordfish conducts extensive vertical migrations during the day, remaining in shallower waters at night (GUITART, 1964, CAREY \& ROBINSON, 1981). Moreno et al. (1991) corroborate this fact off Cuba, reporting higher commercial catch rates by night. Thus, the use of lightsticks leads to higher catch rates during the waxing crescent moon. Since the results of the present study were masked by the use of lightsticks, it is necessary to carry out longline fishing experiments without the use of these artificial devices in order to reach a surer conclusion regarding the effect of lunar phase on swordfish catchability.

The covariance model indicated that the largest swordfish catches occurred in winter. Amorim and Arfelli (1977) and Amorim et al. (1979) report similar results in the same area. The fishery statistics provided by the Fishery Research Group (GEP) also demonstrate larger swordfish catches in winter. This finding may be associated with the upwellings that occur in this season along the continental slope, which are caused by the cyclonic vortices of the Brazil Current, contributing to an annual production of carbon and reaching higher production levels than in summer (GAETA AND BRANDINI, 2006). The encounter of the Brazil and Falkland Currents, which move in opposite directions, is known as the South Atlantic Convergence Zone, which exhibits seasonal latitudinal variation, with its northern boundary positioned at $30^{\circ} \mathrm{S}$ in winter. This oceanographic phenomenon also accounts for the higher catches of swordfish in winter on the continental slope off southern Brazil (STRAMMA AND ENGLAND, 1999; CASTELLO AND MÖLLER, 1977; CIOTTI et al., 1995).

According to the Inter-American Tropical Tuna Commission (IATTC), with regard to longline fisheries, simple hook selectivity tests based on random procedures or the Mantel-Haenszel test should be carried out before developing more complex models (ANÔNIMO, 2008). Kerstetter et al. (2007) examined swordfish CPUE values for the North Atlantic and found greater catches using the circle hook. A lower swordfish mortality rate was also reported using this hook, as $68 \%$ of the individuals were hooked on the external side of the jaw. Conversely, the present study found that the $\mathrm{J}$ hook was more efficient in catching swordfish than the circle hook. However, swordfish survival with the aim of proposing conservation measures, such as tag and release, was not determined. Giffoni et al. (2005) and Watson et al. (2005) also report greater catches using the $\mathrm{J}$ hook, but these authors employed different statistical methods. It is likely that this type of hook is 
more easily swallowed by swordfish, which reduces their chances of survival.

The Mantel-Haenszel procedure proved an appropriate statistical tool for testing hook selectivity aboard commercial and research longliners, since it took into account spatial and temporal variations in longline deployment.

\section{REFERENCES}

ALLEN, R. Estimates of abundance using sighting data. Rep. Int. Whal. Comm., v.30, n.73. 1980.

AMORIM, A. F., ARFELLI, C. A. Contribuição ao conhecimento da biologia e pesca do espadarte $e$ agulhões no litoral sul-sudeste do Brasil. Anais do I Congresso Paulista de Agronomia: 1977. 197 - 199p.

AMORIM, A. F., ARFELLI, C. A., GARCÉS, A., REY, J. C. Estudio comparativo sobre la biología y pesca del pez espada, Xiphias gladius (Linnaeus, 1758) obtenidos por las flotas españolas y brasileñas. Col. Vol. Sci. Pap. ICCAT, 8 (2). 1979. 496 - 503p.

AMORIM, A. F., ARFELLI, C.A. Analysis of the Santos fleet from São Paulo, southern Brazil (1971-1999). Col. Vol. Sci. Pap. ICCAT (53). 2001. 263-271p.

ANÔNIMO. Workshop on turtle bycatch mitigation for longline fisheries: Experimental design and data analysis. 7-8 November 2007. San Ramón, Alajuela, Costa Rica. Inter - American Tropical tuna commission (IATTC). Special Report 17. La Jolla, California, USA. 2008. 52p.

CAREY, F. G., ROBISON, B.H. Daily patterns in the activities of swordfish, Xiphias gladius, observed by acoustic telemetry. Fish. Bull. 79, 1981. 277-292p.

CASTELLO, J. P. \& MÖLLER, O. O. On the oceanographic conditions in the Rio Grande do Sul State. Atlântica (2) 1977. 25-110.

CIOTTI, A. M., ODEBRECH, C., FILLMANN, G., MÖLLER JR., O. O. Freshwater outflow and subtropical convergence influence on phytoplankton biomass on the Southern Brazilian Continental Shelf. Continental Shelf Research, Vol.15, No.14, 1995. pp.1737-1756.

DANIEL, W. W. Biostatistics: A foundation for analysis in the health sciences. Sixth edition. John Wiley \& Sons, Inc. 1995.

DRAGANIK, B., CHOLYST, J. Temperature and moonlight as stimulator for feeding activity by swordfish. ICCAT, Col. Vol. Sci. Pap., Madrid, v.27, Mar., 1988. 305-311p.

GAETA, S. A.; BRANDINI, F. P. Produção primária do fitoplânton na região entre o Cabo de São Tomé (Rio de Janeiro) e o Chuí (Rio Grande do Sul. 2006. 219. $264 p$.

GIFFONI, B. B., SALES, G., CONSUliM, C. E. N., FIEDLER, F. N., PEPPES. F., SWIMMER, Y. Experimento com anzol circular na ZEE Brasileira e em agues adjacentes, para mitigar a caprura de tartarugas marinhas na pescaria de espinhel pelágico. II Jornada de Conservação e Pesquisa de Tartarugas Marinhas no Atlântico Sul Ocidental. 14 e 15 de novembro, Praia do Cassino, Brasil. 2005.

GUITART, G. Biology pesquera del imperador o pez espada, Xiphias gladius Linnaeus (Teleostomi: Xiphiidae) en las aguas de Cuba. Poeyana, La Habana, ser.B, jun., 1964. n.1, 1-37p.

HAZIN, F. H. V., HAZIN, H. G., BOECKMANN, E. C., TRAVASSOS, P. La reproduction de l'espadon (Xiphias gladius) dans l'atlantique sud-ouest equatorial: la ponte et la fecondite. ICCAT, Col. Vol. Sci. Pap 52, 2001. 1233-1240p.

HAZIN, F. H. V., HAZIN, H. G., BOECKMANN, E. C., TRAVASSOS, P. Preliminary study on the reproductive biology of swordfish, Xiphias gladius (Linnaeus, 1758), in the Southwestern Equatorial Atlantic Ocean. ICCAT, Col. Vol. Sci. Pap 54 (5), 2002. 1560-1569p.

HAZIN, H., ERZINI, K. Assessing swordfish distribution in the South Atlantic from spatial predictions. Fisheries Research 90, 2008. 45-55p.

HUITEMA, B. E. The analysis of covariance and alternatives. John Wiley \& Sons, Inc. 1980. 445p.

ICCAT. Report for Biannual Period, 2004-2005, Part I. 2005a. 238 pp.

KERSTETTER, D. W., PACHECO, J. C., HAZIN, F. H., TRAVASSOS, P. E., GRAVES, J. E. Preliminary results of circle and j-style hook comparisons in the brazilian pelagic longline fishery. Col. Vol. Sci. Pap. ICCAT, 2007. 60(6): 2140-2147p.

KOTAS, J. E., PETRERE Jr., M., AZEVEDO, V. G., SANTOS, S. A pesca de emalhe e de espinhel de superfície na Região Sudeste-Sul do Brasil. Série Documentos REVIZEE - Score Sul. São Paulo: Instituto Oceanográfico - USP. 2005.72p.

MORENO, S., POL, J., MUÑOZ, L. Influencia de la luna en la abundancia del emperador. ICCAT, Col. Vol. Sci. Pap., Madrid, Mar., 1991. v.35, n.2, 508-510 p.

PETRERE, M. Jr. Pesca e esforço de pesca no Estado do Amazonas. I. Esforço e captura por unidade de esforço. Acta Amazonica (8). 1978. 439-454p.

STRAMMA, L. AND ENGLAND, M. On the water masses and mean circulation of the South Atlantic Ocean. J. Geophys. Res., 104:C9, p. 20,863-20,883, 1999.

UNIVALI. Boletim Estatístico da Pesca Industrial de Santa Catarina - Ano 2000. Programa de Apoio Técnico e Científico ao Desenvolvimento da Pesca no Sudeste e Sul do Brasil. Grupo de Estudos Pesqueiros (GEP). Itajaí, 2001. 87p.

UNIVALI. Boletim Estatístico da Pesca Industrial de Santa Catarina - Ano 2001. Programa de Apoio Técnico e Científico ao Desenvolvimento da Pesca no Sudeste e Sul do Brasil. Grupo de Estudos Pesqueiros (GEP). Itajaí, 2002. 87p.

UNIVALI. Boletim Estatístico da Pesca Industrial de Santa Catarina - Ano 2002. Programa de Apoio Técnico e Científico ao Desenvolvimento da Pesca no Sudeste e Sul do Brasil. Grupo de Estudos Pesqueiros (GEP). Itajaí, 2003. 87p.

UNIVALI. Boletim Estatístico da Pesca Industrial de Santa Catarina - Ano 2003. Programa de Apoio Técnico e Científico ao Desenvolvimento da Pesca no Sudeste e Sul do Brasil. Grupo de Estudos Pesqueiros (GEP). Itajaí, 2004. 87p.

UNIVALI. Boletim Estatístico da Pesca Industrial de Santa Catarina - Ano 2004. Programa de Apoio Técnico e Científico ao Desenvolvimento da Pesca no Sudeste e Sul do Brasil. Grupo de Estudos Pesqueiros (GEP). Itajaí, 2005. 87p. 
UNIVALI. Boletim Estatístico da Pesca Industrial de Santa Catarina - Ano 2005. Programa de Apoio Técnico e Científico ao Desenvolvimento da Pesca no Sudeste e Sul do Brasil. Grupo de Estudos Pesqueiros (GEP). Itajaí, 2006. 87p.

UNIVALI. Boletim estatístico da pesca industrial de Santa Catarina ano 2006: ações prioritárias ao desenvolvimento da pesca e aqüicultura no sul do Brasil. Itajaí./Relatório técnico Universidade do Vale do Itajaí. Programa de Apoio Técnico e Científico ao Desenvolvimento da Pesca no Sudeste e Sul do Brasil. Grupo de Estudos Pesqueiros (GEP). 2007.

UNIVALI. Boletim Estatístico da Pesca Industrial de Santa Catarina - Ano 2007. Programa de Apoio Técnico e Científico ao Desenvolvimento da Pesca no Sudeste e Sul do Brasil. Grupo de Estudos Pesqueiros (GEP). Itajaí, 2008. 87p.

UNIVALI. Boletim Estatístico da Pesca Industrial de Santa Catarina - Ano 2008. Programa de Apoio Técnico e Científico ao Desenvolvimento da Pesca no Sudeste e Sul do Brasil. Grupo de Estudos Pesqueiros (GEP). Itajaí, 2009. 87p.

WATSON, J. W., EPPERLY, S. P., SHAH, A. K., FOSTER, D. G. Fishing methods to reduce sea turtle mortality associated with pelagic longlines. Canadian Journal of Fisheries and Aquatic Sciences 2005. 62: 965 - 981p.
ZAR. J. H. Biostatistical Analysis (3a ed.). Prentice-Hall, New Jersey. 1996. 662p.

Sources of Unpublished Material

ABUABARA, M. A. Análise dos dados de captura e esforco da pesca com espinhel de atum no Oceano Atlântico Sul de 1974 a 1980. São Carlos. Tese de Doutorado Escola de Engenharia de São Carlos, Universidade de São Paulo. 1996. 105 p.

ARFELLI, C. A. Estudo da pesca e aspectos da dinâmica populacional de espadarte, Xiphias gladius L. 1758, no Atlântico Sul. Tese de Doutoramento, Universidade Estadual Paulista, Rio Claro, São Paulo, Brasil. 1996, p. $175 \mathrm{p}$.

(Manuscript received 22 April 2010; revised 27 January 2011; accepted 22 March 2011) 